organisations concerned, the Association of British Chemical Manufacturers, has recently published a brief survey of its work since its formation in 1916.

THE Association of British Chemical Manufacturers, which now has a membership roll of 117 firms representing a capital of more than $£ 200,000,000$, originated from the proposals of a committee representing the Chemical Society, the Society of Dyers and Colourists, and the Society of Chemical Industry, called at the suggestion of the first-named to consider the best methods of promoting co-operation between British chemical manufacturers. Additional objects served by the Association are : to provide British chemical industry with a medium for the expression of its views ; to further technical organisation and promote industrial research; to facilitate the development and extension of British industries by keeping in touch with progress in chemical knowledge and practice; and to encourage closer co-operation between chemical manufacturers and the various universities and technical colleges. These desirable objects have been steadily borne in mind by the Association, the annual reports of which show a long record of achievement, and it has been prominently associated with all movements of importance since its formation. From its early days, the Association has maintained a service to keep members informed of the import and other statistics essential to their work, to keep them apprised of all directions in which new manufactures are needed, and yet at the same time to prevent useless overlapping by unnecessary duplication of effort. The Association is closely concerned with questions of safety in chemical works, with matters arising out of the Import Duties Act, with negotiations leading to new commercial treaties with foreign countries, with the incidence of acts such as the Dyestuffs Act and the Patents and Designs Act, with transport and with exhibitions. The monthly summary of information on chemical trade can be purchased by non-members.

\section{Jubilee Exhibition at the Science Museum}

To mark the occasion of His Majesty's Silver Jubilee, a pictorial exhibit illustrating the more outstanding inventions and conspicuous developments of the past twenty-five years has been arranged at the Science Museum, South Kensington. This exhibition was opened to the public on May 1 and will remain on view during the whole of the month. The main advances in the pure sciences, astronomy, mathematics, physics, chemistry, meteorology and geophysics are illustrated, together with their more important applications; for example, photographs are shown of the planet Pluto (which was discovered in 1930), modern methods of upper air investigations, radio-gramophones, 'talking pictures' equipment, infra-red photography and modern methods of prospecting. Of special interest is the series of photographs showing the rapid advances which have recently been made in our knowledge of the constitu. tion of the atom, and the structure of the atomic nucleus. Progress of chemical industry is shown to include many important developments such as the low-temperature carbonisation of coal, the manufacture of insulin, artificial silk and plastic products; while in the case of glass manufacture, reference is made to the improvements resulting from the intro. duction of machine processes and the influence on the glass industry of the widespread use of the motor-car. Among other subjects represented may be mentioned the development of aircraft, ships, locomotives, motor-vehicles, steam turbines, oil and marine engines, while the advances in electrical power and communication are illustrated by modern electric power stations, automatic telephones, radio-com. munication and television.

\section{Award of Kelvin Medal to Sir Ambrose Fleming}

THE Kelvin Medal of the Institution of Civil Engineers, which is awarded triennially as a mark of distinction in engineering work or investigation of the kinds with which Lord Kelvin was especially identified, was presented to Sir Ambrose Fleming by Sir Kingsley Wood, Postmaster-General, on May 7. Referring to our dependence on the universities for the inception of new scientific methods and scientific knowledge, Sir Kingsley said that thanks are due to Sir Ambrose not only for his own contributions, but also for the inspiration he has given to generations of students, which have spread over the world in ever-widening circles like the wireless waves themselves. Sir Ambrose was one of those pioneers in the science of radio, who worked under both physical and financial difficulties, and yet succeeded in placing at our disposal a means of communication of thought, sound and vision. Broadcasting may well be one of the greatest factors in drawing together the nations of the world. Sir Kingsley said that mass production in research produces results, but at a relatively higher cost than the research of inspired and gifted individuals, which has hitherto characterised the majority of the investigations carried out in Great Britain.

\section{Viruses and Heterogenesis}

The definition and nature of life have been favourite subjects for ancient and modern discussion. Sir Henry Dale, armed with many recent exact data, stated in the Huxley Memorial Lecture on "Viruses and Heterogenesis", delivered at the Imperial College of Science on May 2 (London : Mac. millan and Co., Ltd. 1s. net), the dilemma which confronts those who attempt to decide whether all the viruses which cause disease are self-propagating micro-organisms or whether some of them do not originate from the tissues of the host. Admitting that their minute size is perhaps the most important obstacle to accepting the smallest viruses as frankly living, he pointed out that there is an unbroken series from a virus of about the same size as the smallest bacteria with a diamoter of $750 \mathrm{~m} \mu$ to the virus of poliomyelitis estimated at $10 \mathrm{~m} \mu$, which approaches the size of a protein molecule; the diameter of a molecule of egg-albumin has been calculated as $4.33 \mathrm{~m} \mu$ (1 $\mathrm{m} \mu=$ one millionth of a millimetre). The long category of viruses has several 